\section{Image, Ritual and Urban Form: Porto in the 16th Century}

\author{
José Ferrão Afonso \\ jafonso@porto.ucp.pt \\ Universidade Católica Portuguesa (UCP) \\ CITAR: Research Centre for Science \\ and Technology of the Arts, Portuguese \\ Catholic University.
}

$+-$

fore, the late Middle Ages, which Huizinga classified as deeply iconophile, in which image and ritual were put at the service of the reformulation of a State becoming increasingly centralised and interventionist, whose action extended to the sphere of the Church: with King João II, and especially King Manuel I, the Crown was an active sponsor of religious reform that was pursued with redoubled energy and systematisation, from the reign of "the Pious", then already within the political system of close bilateral cooperation that was designated the Confessional State. We therefore believe that this type of approach to anthropological and symbolic components, which seeks to take into account the increasing importance that is given in contemporary research on the city's history, can be very fruitful.

\section{1 | Porto at the end of the Middle Ages: from absolute space to the city of the King}

The city in the High Middle Ages was identified with its own symbol. For the Neoplatonic tradition, which dominated the cultural landscape of the Christian West until the 13th Century, there was not a city but "the city", or Celestial Jerusalem. This objective identification was still present in Roman Porto, sheltered behind its ring of walls, that Bishop Hugo and his immediate successors developed after 1120. However, the demographic and economic progress associated with political change would bring into question, especially after the crisis of 1190-1210, the absolute, theological and symbolic space of the Roman town. The main agents of this argument were the Mendicants, who arrived in Porto in the third decade of the 13th Century, and settled in the far west of the peripheral belt that they helped define, west of the Roman walled acropolis of Penaventosa, covering the lower part of the Rio da Vila valley. The Mendicant convents and their enclosures helped

HUIZINGA, p. 147

\footnotetext{
According to tradition, this was the advice given by Francisco Pacheco to his apprentice Velásquez (FOUCAULT, p. 64).

2 AFONSO, José Ferrão. A imagem tem que saltar ou o rebate dos signos. A cidade episcopal e o Porto intramuros no século XVI. Propriedade, ritual, representação e forma urbana (1499-1606) [Roneoed text]. 3 vols. Barcelona, 2008. Dissertation (PhD in the Theory and History of Architecture). School of Architecture, Barcelona, UPB.
} 
to determine the administrative boundaries of the ecclesiastical "Civitate" of the 13th Century. The strength shown by the "Civitate" and their masters the Bishops was expressed, for example, in the creation of the orthogonal extensions of Lada and Miragaia, true "new towns", and in the administrative and sacramental affirmation of an urban territory. They contributed decisively to the latter by implementing more efficient taxation, and the division of properties between Mitra and Cabido occurred c.1200. These developments, however, postponed affirmative urban action on the part of the Mendicants, so only from the early 14th Century (the Dominicans, for example, only completed their convent in 1320) was there a significant decryption of the symbol and with it of the absolute space of the episcopal seigniory's city. The new urban ideology of the Common Good, based on Aristotle and refined by Thomas Aquinas and his disciples, played an important role in this transformation, and therefore became associated with the slow emergence of an urban landscape, with the fullness of morphological, social, stratigraphic and symbolic meaning with which it is connoted.

In terms of morphological plan, the urban landscape of the 14th Century resulted in the gradual urbanisation of the waterfront, between S. Nicolau, Barredo and Lada, and the development of the arterial route which we shall designate "Rua Direita" (Straight Street). Taking as its basis ancient layouts, among which is the Roman road through Amarante/Penafiel/Porto/Lordelo/Matosinhos/Vila do Conde [5] it goes around the Roman borough of Penaventosa. Successive sections formed its main branch which, from the eastern plateau, skirting the episcopal city radially, extended to the riverfront and the Douro: these were the streets called Cimo de Vila, Chã, Escura, Bainharia and Mercadores. A sec-

[5]The street, which in Lordelo ran to Matosinhos, was an old Roman road. It entered the Roman enclosure, originating in Penafiel and after passing by the fortress of Vandoma, Valongo da Estrada and the pre-Roman church of Santo Ildefonso, by the Vandoma gate. Inside the Roman walls, in the Low Middle Ages, it was called Rua do Redemoinho and Rua das Aldas; leaving the lower area of the enclosure by the Souto gate, later known as Santana and, after crossing the Rio da Vila valley, skirting the convent of S. Domingos - and the chapel which preceded it - it climbed the Olival hill by the so-called S. Domingos path. After passing the point where the Virtudes wicket gate was, it ran along the valley of the Rio Frio in Miragaia to be joined, in the Viriato square, by another Roman road, which started from the banks of the river Douro on the Monchique path. It continued westward along the Sobre-oDouro road, and then via Massarelos, Arrábida and Lordelo (see note below). ond route developed from it: starting from Cruz do Souto, in axial continuity with Rua Escura, it crossed the Rio da Vila valley, climbed the Olival hill, the old "Mons Menendi Olarii", reaching the Roman roads from Braga and Vila do Conde on the plateau. This was named "Karraria Antiqua". [6]

In Rua Direita, the static Episcopal Civitate gained a dynamism that accompanied the economic development and cultural and political transformations. This right of way was for tradesmen and merchants; and the latter, especially, would form an urban elite who would find in the Mendicants, especially in the Dominicans, their ideologues and preferred allies. In Rua Direita, the market, originally associated with ecclesiastical seigniorial power, descended the Penaventosa hill, departing from the sacred. The street and the urban landscape it ran through therefore became inseperable from a slow but inexorable deepening of the decline of the Episcopal seigniory and, at a later stage, the entry in force in the city of a new urban protagonist: the Crown.

The new urban plan affected the spatial organisation of the episcopal "Civitate", still anchored in the sacredness of a network of small nuclei, clustered around chapels and their cemiteriae which, in turn, was structured in a close relationship with the ancient long and medium range territorial Roman roads: S. Nicolau, Miragaia, Santo Ildefonso, the Cathedral preceded by a pre-Roman chapel - the "ecllesia" in the Rio da Vila valley that preceded the convent of S. Domingos, perhaps the chapel of Santa Cruz, located on the site where the Carmelite convent would be built, next to the Roman "Karraira Antiqua" and that of S. Miguel, also bordering the Roman road from Braga [7]. The road system that, from the 14th

[6] The Roman road that joined Lisbon and Braga, via Coimbra, crossed the Douro at Castelo de Gaia, in the place where Senhor da Boa Passagem is today. At the opposite bank, the alighting point was at Monchique in Miragaia, at the foot of the pathway of the same name, which climbed the slope of Monte dos Judeus along the route of present Rua da Bandeirinha. In Viriato square it veered towards the north, to Carregal, which it reached after crossing Rua de Cedofeita, Rua Mártires da Liberdade and thence to the north, to Braga (cf. AFONSO, José Ferrão. A Praça da Ribeira (1st part). Revista Mvseu (at press).

[7] Starting from Miragaia, the "Via Vicinal", coming from Lisbon and Coimbra, and going on to Braga, climbing the Monchique path (a name that may be associated with Mont Juif and was already in use at least by the middle of the 14th Century; the settling of the Jews along the route may have been due to its commercial significance. Nearby, on the site where today stands the Palácio das Sereias, on the Quinta da Bandeirinha, stood the Jewish cemetery or Estrepão), Bandeirinha and Carregal until it reached the current Rua dos Mártires da Liberdade and, from there, the Northern interior; from S. Nicolau, there was an extension of it, climbing 
Century, would be complemented and interconnected by a finer network, that was more responsive to the local economy and the route to the sea. Its development was initially allowed by the greater security of the coast after the conquest of Lisbon, which facilitated the reuse of the Roman coast road from Lisbon to Braga. (Figure 1)

The close articulation of the new road network formed a new urban capillarity. With this, the universal ubiquity of the Penaventosa acropolis gave way to a locus associated with an incipient but effective form of representation of the space, creating a material, active and industrious centrality in the Dominican convent in the Rio da Vila valley. In the vicinity of Pregadores, Rua Direita led to Ribeira, near Barredo, contributing to the displacement of the old bolt crossing point, originally between Gaia and Miragaia, then between Gaia, Vila Nova and S. Nicolau, to the east. In this way, it articulated with the development of new routes at the opposite bank: Rua Direita in Vila Nova, extended in a southerly direction, Rua Direita in Porto.

The 14th Century plan, anchored in traditional principles such as the circle and the cross, which informed the urban symbolic forms of the High Middle Ages, and after them, the geometry and layout of regulated urbanism, had in S. Domingos a moral epicentre of order, social identity, harmony and Christian values. Socially and politically, this nucleus was embodied and strengthened in the alliance with men of the Borough. It was the incarnate image of the Common Good, which the theological tradition of the late Middle Ages identified with the city itself. The Common Good, however, was not egalitarian. Its two fundamental ideas were that the whole is greater than its parts and that the originality of these should be respected. For Thomas Aquinas there was one law for the merchants and quite another for the

Belmonte between the walls of the Mendicant convents, then the Olival hill, continuing via "Karraria Antiqua" - later Rua de Cedofeita -to the Ave, intersecting with the former near the present Largo de Carlos Alberto. The Cathedral and Santo Ildefonso were bordered by the Vila do Conde/Matosinhos/Lordelo/Penafiel road, which was linked, in Massarelos, with another access road to the Ave, the "Via Veteris": this joined the "Karraria", after passing the Colegiada de Cedofeita, at Padrão da Légua and, on Olival, intersected with the road coming from S. Nicolau near the western end of the Calçada de S. Domingos, after rounding, where the Mendicant convent was built in the 13th Century, another old chapel. Finally, the Alfena/Guimarães road left from the Vandoma Gate in the Roman wall taking a course that, before reaching the shallows known as "portu de Carros", was named Rua de Carros (Cf AFONSO. A Praça...). On the Roman road from Vila de Conde, the "Via Veteris" and the "Karraria", also see: ALMEIDA, p. 167 et seq FREITAS, p.50 et seq. and ALMEIDA, Brochado de, p.155 et seq knights, and if the idea of a unitary image of the city is dominant, he also states that its specific components should be respected, insofar as they contribute to the communitas. (Figure 2 e 3 )

The city of the Common Good was short-lived. The arrival of the Crow in Porto occurred in 1325, with the construction of the Customs House in Ribeira, and the Episcopal seigniory lost, effectively, all its powers in 1343, shortly after the Borough obtained, in 1316 and 1331, the ownership of incipient but strategic public spaces of the Episcopal seigniory, some of them probably considered under the "protection" of the Church. Particularly notable among them was the Olival, very important because of the various Roman roads that crossed and intersected on it and, due to its mercantile relevance, the Ribeira with its rossios. The weakness of the Borough, however, was that it was powerless to create a consistent public space and the urban planning that went with it. This role was reserved for the Court, which quickly integrated into its circles the elite urban merchants from whom it had sought support in order to obtain results in relation to the Episcopal seigniory.

In 1405, under King João I, the long agony of the Episcopal seigniory came to an end with its acquisition by the Crown. In practice, however, the new restricted Borough, consequent to the Law of Municipal Powers (1391) that substituted it, made it into a true urban collective seigniory which saw its territory successively enlarged by King Fernando I and by the Lord of Avis. In one gesture, at once of symbolic-spatial appropriation and challenge, the Borough erected its new municipal building on the Roman wall of the Bishopric, next to the Cathedral towers. The new Town Hall therefore coincided with the final extinction of Episcopal power. It reused, however, the crenellated tower that was its significant morphology. A novelty was introduced, however: the square tower gave way to a structure that adopted the rectangular shape of the long and narrow bourgeois plot that had developed from the 14th Century in Rua Direita. The formal invariability, characteristic of the objectivity of absolute space, gave way, little by little, to the variability of subjective representation.

The city of the King would be the fragmented, nominalist and exclusive city of the late Middle Ages. Representation, which was its main driving force, was expressed in the restrictive social topography of the levelling urban layout of Rua Nova and the Jewish quarter, and in the market in the newly created Ribeira plaza. King Afonso $V$ compared Rua Nova to his palace: "... the street was the saloon and the houses the chambers, the monastery was

[8] BARROS, p. 38. 
the chapel and the plaza the garden ..."[8] The city, indeed like the house, no longer coincided with a universal symbol, being understood as a collection of private spaces. In Rua Nova and the Jewish Quarter, these were exponents of regulated planning that the Borough had not been able to undertake throughout the century, since, in 1316, King Dinis had supported its claims to the public squares of the episcopal city. However, in Praça da Ribeira, a space for royal representation delegated in the municipal power, the councillors were unable to build a consistent morphology.

Throughout Europe, the aristocratic verticality of Arèvalo succeeded the horizontal and mendicant communitarianism of Eiximenis, and the 14th Century city displayed inside its walls three divisions of landscape with very different nuclei of property, social and economic components, stratigraphies, morphologies and meanings: Ribeira, with Rua Nova and the square of the same name, the Olival with the Jewish Quarter, and the eastern part of the city with its sacred Roman nucleus. This city, however, resulted directly from the city of the Common Good that preceded it. Thus, the royal wall that encircled Porto in the 15th Century, with its gates and two convents - Santa Clara and Santo Elói - which were erected inside it in the 15th Century, as part of the first movements of the Reformation, still depended on the plan centred on S. Domingos (fig. 1, 2, 3). The dysfunctionality of the 14th Century town, however, was felt from early on and the image used by the "African" implied a desire for social aggregation that would be the hallmark of the Renaissance city. It would then be the appropriate time for Alberti to revisit and update an old idea of Isidore of Seville:

...If (as the philosophers maintain) the city is like some large house, and the house is in turn like some small city, cannot the various parts of the houseatria, xysti, dining rooms, porticoes, and so on-be considered miniature buildings?.[9]

The main agents of the aggregation of the city from the late Middle Ages were, however, neither architects nor urban planners: This role was, in some way, played by ritual. The procession of "Corpus Christi", whose first record dates it back precisely to Porto in the reign of 1417, would help identify society, morphology and symbol around a sacred image. Its iconic language offered citizens a very special intimacy with the saints and relics, and through it, a foretaste of a desired and promised collective future salvation. Images and relics had intensely meaningful relationships with urban spaces, not just because devotees wanted to see and touch them, but also

[9] ALBERTI, Leon Battista. De re aedificatoria, 1.9.Apud FRUGONI, p.4.

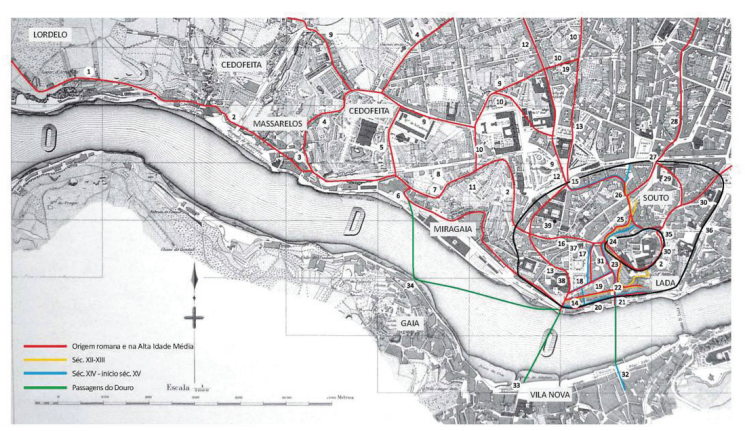

Figure 1: Porto in the 15th Century

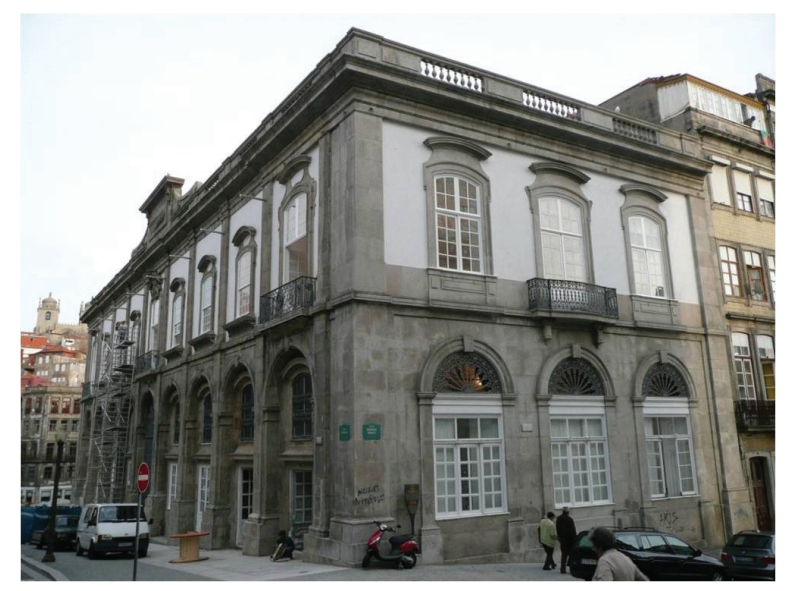

Figure 2: Old porch of the Convent of São Domingos
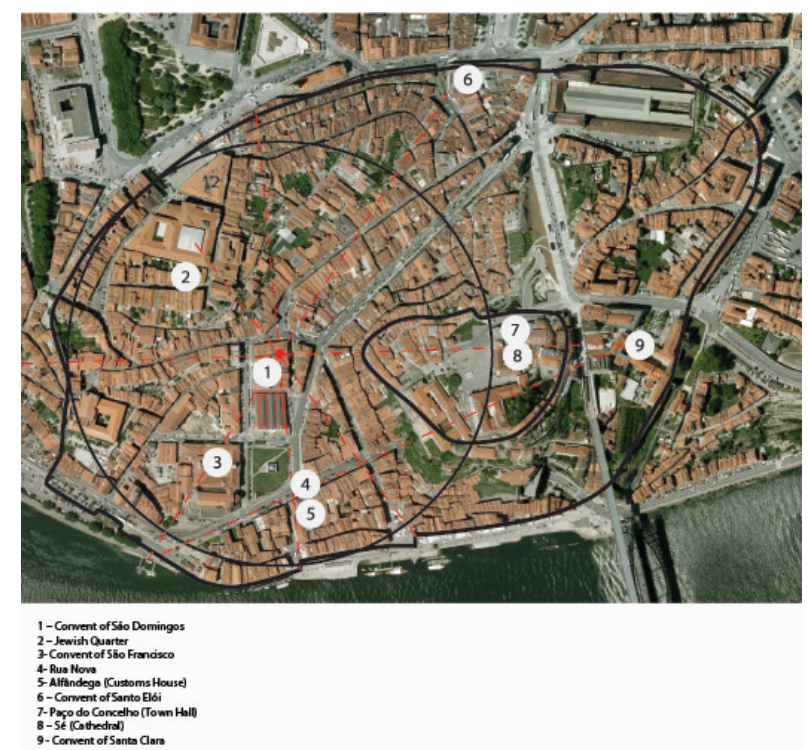

Figure 3: City plan in the 14th century 
because parading them around the city celebrated, like the Mendicant plan, the "communitas", bringing the urban space close to man. The processions transformed the city of the late Middle Ages into a place of continuous moralising representation. At the same time, they were supposed to contribute to the affirmation of a public space which their persistent parading helped design. Moreover, and no less important, their ability to invest the city with meaning could condition it socially and therefore morphologically.

At the end of one era or, if you like, at the beginning of another, the processions also served to affirm the supremacy of the Cathedral in the urban space; therefore to displace there a centrality that the Common Good concentrated in S. Domingos. The entrance of Porto into 15th Century Modernity coincided, therefore, with an event of major urban consequence: the transfer of the icon of St. Pantaleon, mysteriously borne away in 1453 to the outskirts of Miragaia, to the Cathedral. Thus, a 'natural' order was reinstated: the route from one peripheral point to a central and definitive place, culminating in an exemplary way the rite of passage that had begun in Constantinople.

\section{2 | St. Pantaleon}

The image of the mystical body, created by St. Paul and then combined with the ancient organicism in Polycraticus of John of Salisbury (1159) was, from the 14th Century, also applied to the political community. While it had already informed the Dominican centrality of the 14th Century urban plan, in the 16th Century it would be one of the recurring metaphors to signify the order and harmony of the republic, with the King at its head. It would also be crucial in the urban reformulation which then took place. On 12 December 1499, Bishop Diogo de Sousa, in solemn procession, transferred the relics of St. Pantaleon, deposited in the parish church of S. Pedro de Miragaia, to the Cathedral [10]. Relics are instruments of power, both immanent or "internal" and

[10] CUNHA, vol. 2, p182, NOVAIS, part 2, vol. 3, p. 223-234. Recent historiography does not question, in general, this repatriation; the same is not the case, however, with the solemn procession through which, according to D. Rodrigo da Cunha and Pereira de Novais it would have been carried out (MACHADO, A., p. 199). Resende Mendes suggests that it may have been done, not in the pompous ceremony mentioned by the two 17th Century authors, but in "...a discrete and economical act-that of making use for the benefit of a cathedral without relics of any significant value of the bones of the thaumaturge, which were marginally worshipped in a church outside the city walls..."(MENDES, p. 135-136).Carlos Azevedo, however, classifies it as "pure historical truth"(Azevedo, p.104). social, or "external"; in the latter case they had the ability to transfer power to the institutions that possessed and worshipped them, and also to the whole of society. In this sense, the interest of the Crown can be understood, and the important role it played in encouraging the cult of St. Pantaleon. In fact, it was King João II (1481-1495) who made a decisive contribution to establishing the Pantaleon following. In his will, dated 1495, he gave detailed orders for the construction of a silver chest for the relics, and it may be that the monarch visited them in the church of Miragaia when he was in Porto between November 1483 and January 1484, since a cult of S. Pantaleon in the parish church is documented as

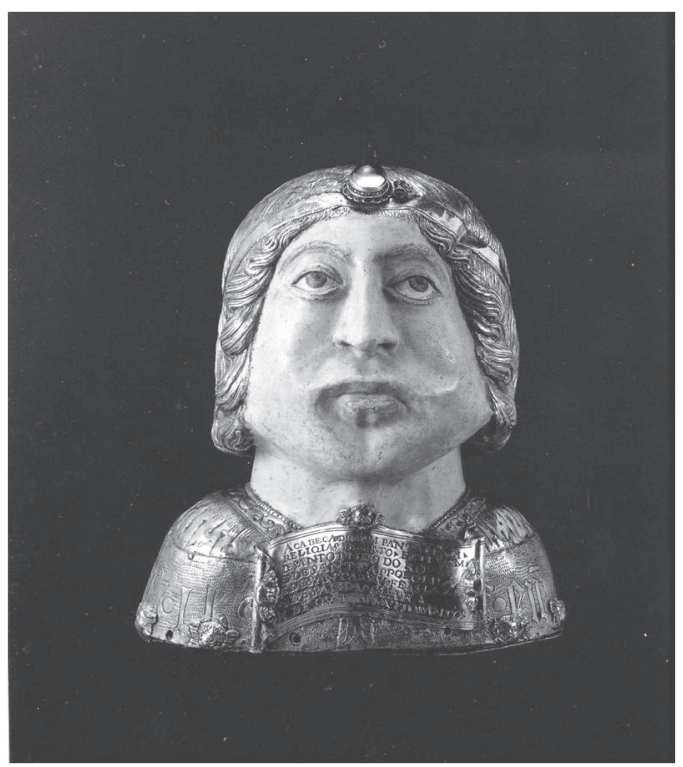

Figure 4: Reliquary of São Pantaleão

existing since 1478 (fig. 4)

The concern of King João II and the care with which, in his last will, he referred to the construction of the silver chest surprise the researchers. Such attention may even mean that the King was involved in the mysterious arrival of the sacred relics in Porto, at a time when, after the fall of Byzantium in 1453, Europe was beset by reports of sacred spoils coming from New Rome, the former Constantinople, and that the crusade against the Turks was the issue of the day. It is no surprise, therefore, that it was Diogo de Sousa, Bishop of Porto from 1495 to 1506, who had been Dean of the Chapel of the "Perfect Prince" in Évora, and was sent by him as ambassador to Rome, who ordered the transfer of the body to the Cathedral. The prelate would have been well aware of the power of relics: in Braga, already raised to an Archbishopric, he would continue this policy, and it was not by chance that he was associated with an ambitious urban renewal plan.

At the end of the Middle Ages, as stated by St. 
Bernardine of Siena, it was the objects, not the places, that were sacred. The centre, a space at once mental and social, had become extremely volatile and the supernatural power of the relics once more deposited in the Cathedral would contribute to its fixation. The anthropomorphic theory, which had already served the Mendicant plan, was now put at the service of the State, so that the interest of the Crown in the development of the Pantaleon cult would not peter out with King João II. His successor, King Manuel I, when he passed by the city on his way to Compostela in late 1502, ordered the completion of the chest, but slightly altered the last wishes of his predecessor. He ordered that the chest should display, on the external face:

"...Images of his Martyrs and Passion, those that reasopnably fitted around his tomb on the outside face, since it shall have no silver or images against the wall..." $[11]$

. What was actually made under the orders of the "Fortunate" is described in the Catálogo dos Bispos do Porto:

"... On it can be seen the arms and designs of the two Kings who commissioned it to be made, the five shields of Portugal being on one side, and on the other the Pendant of King João the Second, a Symbol with which he wished to demonstrate the love that he had for his people. In the middle of the two insignia is the image of the glorious Martyr, the patron and protector of the City..." [12]

Devotees could not ignore the royal heraldry when they were praying in the Cathedral, or saw the sacred icon in procession through the streets of Porto, and St. Pantaleon was not the only case in which the advent of relics was associated with the emergence of a new cycle of political power. While, under King João II, the beginnings of a Modern State in Portugal were put in place, this plan was be continued and even intensified institutionally with the ascension of Manuel I to the throne. His key idea was to convert the old fragmented mediaeval country into a unified national territory. Bearing in mind this aim, which was far from being achieved, the visibility of the King in the land was essential. This, however, could not be done only with his physical presence, so other means were also employed through his symbolic representation.

The marked tendency to embody thought in images, which was a feature of Western culture from the 15th Century and one of the structural characteristics of the mindset of the time, was accentuated in the case

[11] SOUSA, D. António Caetano de. Provas da história genealógica da Casa Real Portuguesa. Coimbra : Atlântida - Livraria Editora, 1947, book 22, part, p. 210. Apud MACHADO, p.195.

[12] CUNHA, vol. 2, p. 184-185. of King Manuel, due to the particular circumstances surrounding his ascent to the throne. The new political cycle and new iconography also assumed a new type of relationship between the Crown and the Church; it was, in the 16th Century, and following a trend that came from the past, different from what was practised in the Middle Ages. If the Portuguese monarchy did not have a tradition of the sacredness of royal munus, with King Manuel, if it was not completely assumed, it was at least strongly suggested. The Church was duty bound to the will of the Christian monarch, or at least should cooperate with him in the plans to reformulate the State. To this end, royal power extended its remit to ecclesiastical reform and control of the clergy, while the inclusion of the sacred in the political would have been a sine qua non condition for the survival of the Church as an institution. In Porto, this political alignment of the clergy was facilitated, in the first half of the century, by the fact that there was a succession of courtesan bishops holding office. We have already referred to D. Diogo de Sousa and the important part he played in the transfer of the relics, but others followed: D. Diogo da Costa, D. Pedro da Costa, D. Frei Baltasar Limpo and D. Rodrigo Pinheiro. The removal of the remains of the Holy Martyr to the Cathedral was not, therefore, associated only with the establishment of a new urban centre. It was an essential part of the construction of a cultural system, equally "central", with renewed religious, symbolic, ideological and morphological values. A system that would, through the sacred, be able to influence the behaviour of the people, and whose model can be found in the "Roma triunphans" of Nicholas V. The city of the popes was therefore reinvented according to a set of rituals, liturgical revitalisation and works directed at both the spiritual and the temporal, which would be crowned by the affirmation of the centrality of St. Peter's in the Vatican.

In this way, the intense urbanistic activity that occurred in the first half of the 1500s in Porto is indissociable from the Pantaleon traslatio and its significance. Both were instrumental in the programme undertaken by the Crown, which relied on the close cooperation of the Church and its Bishops. Both were also efficient and highly elaborate forms of representation and, as such, overcame the limitations of an ineffectual State apparatus that, rather than being the motor, was often an obstacle to the political aims of the State. Another form of representation, equally complementary to the State apparatus, was the construction of formally regular, or regularised, urban landscapes. The development of the Pantaleon cult was therefore accompanied in Porto by the remodelling and regularisation of the daily Market Square in Ribeira, commissioned by 
King João II after a fire there in 1491.

Thus, the affirmation of the central sacred space through the repatriation of the relics had a parallel in the royal redefinition of a secular centre for the city which, due to the contingencies of local history and the premature assertion of the market, unlike what happened in most Portuguese towns, had prematurely separated itself from the religious core. This parallelism was common in European cities towards the end of the Middle Ages. Other interventions occurred at the same time: there were works to extend and regularise the facades on Rua das Eiras (1495), near the entrance to the cathedral close, as a result of the opening of a route that connected it to the Santa Clara wicket gate, where the Santo António do Penedo Chapel was erected. Shortly afterwards, when he passed through the city in 1502, King Manuel ordered the facades of the houses in Rua Nova to be regularised.

The renovations undertaken by the Crown did not signify a revolution, however. In fact, they took place following the appropriation of local practices and prerogatives that had often been granted as a privilege by the rulers. This was the case with economic regulation, tax collection and the exercise of Justice; from the 14th Century, through its progressive control, the State began to expand its functions. The practice of regulated town planning was also part of this process. It came to a climax with King Manuel, with a profusion of laws and regulations, particularly in the street layout of Lisbon. In Porto, with its rules about frontages and materials, there were also examples of this process, first in Rua de Belmonte, then in Rua das Flores.

Rua de Belmonte, between S. Domingos and the monument of the same name, was built by Royal Decree in 1503, straight after the visit of Manuel "the Fortunate" to the city. It was the first of a series of interventions that focused on the belt of old Mendicant convents, most of which were ecclesiastical property. This was followed by the link from S. Domingos to the riverfront, effectively using a route that substituted the old Roman road which, from S. Nicolau, climbed the hill to the S. Domingos road, which, as we have seen, was a stretch of the Amarante/Penafiel/Porto/Matosinhos/Vila do Conde road. This route included two streets, initially called Rua Nova de S. Francisco (ca. 1520) and Rua da Rosa, or Rua das Rosas (1523). The former, which met King João's Rua Nova, was carved out of the enclosure of the Franciscan convent; the latter, as well as Rua de Belmonte, out of the Dominican vegetable gardens.

The new street met the new Rua das Flores which, heading North, joined S. Domingos at the Benedictine convent of S. Bento da Avé-Maria. This convent, a "cittadelle sacrée" of royal origin, was founded in 1518 to host female members of the urban aristocracy, in an area of gardens and orchards belonging to the Bishop, next to the Carros wicket gate, near the old "portum de rriuo de Carros" river crossing and the road from Guimarães, in front of the Santo Elói monastery. The location of the convent therefore followed the dual tradition of urban convents: the sacralisation of the city gates and their proximity to important thoroughfares.

Rua das Flores, which linked the two intramural hills of Olival and Penaventosa and, at the same time, balanced the city from Ribeira to the North, used a written, semi-orthogonal topography which included cross-streets and service roads. It also incorporated into its peripheral system new streets like Ponte Nova, Calçada dos Canos, Calçada da Cividade and Rua de Carros, later Rua Nova de S. Bento, now Rua do Loureiro and squares such as Largo de S. Domingos, Largo da Cividade and Largo de S. Bento. On the Southeast, the articulation of the system with the episcopal city, Rua Nova and Ribeira was also implemented through the great activity that the Dominicans built up during the first quarter of the century in the environs of their monastery, successively parcelling out the banks of Rua da Ponte de S. Domingos (1514), Rua de S. Domingos (1514) and the upper part of Rua das Congostas (ca.1524). Not only the Convent of S. Bento da Avé-Maria, but the whole new road system that made up the Manueline plan for urban expansion, including Rua de Belmonte from east to west, and Rua da Ferraria, Rua da Rosa and Rua das Flores [13] in the north-south direction,

[13] The layout, along Rio da Vila, between S. Domingos and the Carros wicket gate was divided into two segments at the end of the Middle Ages. The first, to the south, between the Dominicans and Rua do Souto (now Rua dos Caldeireiros) was occupied in the 16th Century by the Rua das Flores proper; despite there being documentary records of another path, earlier than this road, it was of very little importance, pedonal and practically private. This, however, was not the case between Souto and the wicket gate, the route taken in the 16th Century by Rua dos Canos. This was an important, public route, because it linked, at the right bank of the Rio da Vila, the old "Portu de Carros" and the road from Guimarães that passed there, with the episcopal city, through Rua do Souto. It should be noted, however, that the use of the Carros wicket gate in the 15th Century was intermittent, and it is possible that the nearby Santo Elói or the Fonte da Arca wicket gates, replaced it for traffic from the Guimarães road. The construction inside it of an inn, and the location of the Rocamador Hospital nearby point to this possibility. However, none of this stopped the general south-north direction that the link between S.Domingos and the Guimarães road took being important in the formatting of the 14th Century city and walls. This, however, was only completely acknowledged with the building of Rua das Flores in 1521 
as well as their intersection opposite S. Domingos, were offset by the main drivers of the 14th Century plan. It therefore continued to be the most powerful formative element in the intramural urban landscape in the 1500 s (fig.5).
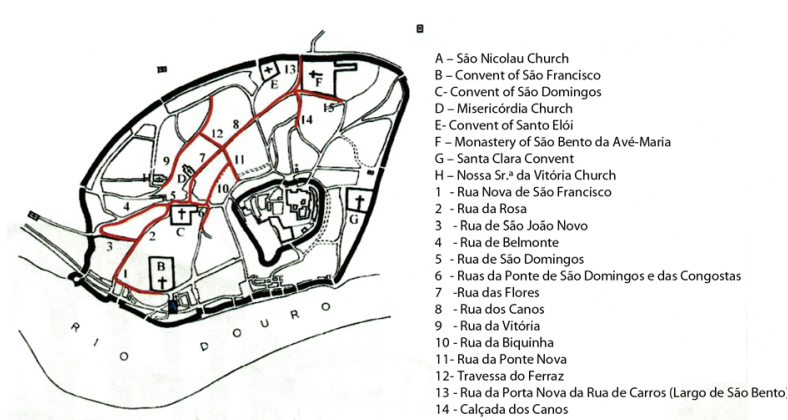

Figure 5: Urban expansion during the 1st half of the 16th Century

However, it would be wrong to confuse the urban creation of the time in the Rio da Vila valley with what preceded it. If they have points in common, if both followed the plans, controlled by the political power, which exhausted their capacity for organicity, in the 1500s the planning techniques that this power had were more refined, for the ability to measure space, the intensification of the regulations and their application, for the spatially expressed will to create social topographies and for the conditioning of the relationship between architecture and the surroundings. There was, therefore, in the 16th Century planning of the valley, an implicit connection between the power, the architecture and the urban space. However, unlike what happened in the absolute space of the 13th Century Civitate, for example in Lada or Miragaia, it required effective external codes, iconographic or linguistic, so that the integrity of their spatial experience was completely grasped. The Royal arms were therefore placed on the Gate of Miragaia, while an inscription in Latin referring to the opening of Rua das Flores by King Manuel was engraved on the New Gate of Carros, and Rua das Flores and Rua dos Canos, destined respectively for the aristocracy and the master tradesmen, were the object of various façade rules, more extensive in the former. It is therefore in King João's Rua Nova and its innovative capacity of representation that we should look for the immediate precedents of 16th Century developments, because its houses had to display icons depicting the various holders of the direct control of housing, especially the Bishopry, the Chapter and S. Domingos. Thus, social identities were created and conditioned, also, through the perfect and precise embodiment ability with which the image was already at that time invested.

But the ideological programme that the Modern
State was endeavouring to implement, of which urban planning was one mechanism, would not be totally effective if it did not also try to achieve emotional identification with its subjects. New cults were therefore instituted: the dynastic around King Manuel and, in the case of Porto, of St. Pantaleon, stand out amongst them. The same aim of a direct link to the subjects, accompanied by the shaping of the image of the ideal prince, determined the elaborate entrance of "the Fortunate" into the city in 1502. This emotional identification also relied on an appropriation of sacred ritual. While it explained the political component since the Middle Ages, the novelty in the 16th Century was a change in the outlook of this component. In this way, instances of royal interference would follow, at the beginning of the century, in the city's main celebration, that of "Corpus Christi". If, in the past, and particularly for the great importance the Borough had in the organisation and financing of the festivities, it took on many of the relevant aspects of a civic religion, with the community element that the term supposed, then royal supervision, which would be implemented with Bishop Baltasar Limpo (1537-1550), with the active collaboration of the bishopric, would tend to devalue this character. While, formally, it continued with the hierarchical participation of the clergy, the elite and the master tradesmen, it would be toned down in terms of a general meaning in which the rite tended to be increasingly institutionalised, with increasing signs of royal meddling in it.

\section{4 | Baltasar Limpo}

It is possible to divide 16th Century Porto into two distinct periods, separated by the figure of the Carmelite Bishop Baltasar Limpo. In the first, which covered the reign of King Manuel and the first part of the reign of his successor, King João III, the city was developed and expanded through the development of the Rio da Vila valley. "The Fortunate" was also concerned with improving navigational and access conditions in the Douro: the Marca Tower was erected in a place, Cristelo, where there was already an Arab "almear", the fishery grounds were removed, a jetty was constructed and improvements were made to the entrance to Ribeira, making it an important axis for drainage formed by Rua Nova de S. Francisco, Rua da Rosa, Rua das Flores and Rua dos Canos which intersected with the old Braga, Vila do Conde and Guimarães roads.

In a second phase, and pursuing this policy, Porto was also preoccupied, as a result of the initiative of the Bishop of Viseu, D. Miguel da Silva, with the improvement of its outlet to the sea, which led to the creation, in Foz do Douro, of an elaborate humanist, urban and architectural programme carried 
out by D. Miguel's private architect, Francisco de Cremona, following his return to Portugal in 1525. In Foz, the speed of Mercury rode the fluidity of the Neoplatonic "chõra".

The friendship of D. Miguel da Silva with the city's New Christian converted Jesus circles which, little by little, were replacing the old patrician elite in mercantile activity, increasingly associated with the landowners' and tenants' lifestyle of the gentry, suited well their construction policy and the demonstration of the capacity for individual initiative that they assumed. In fact, it is highly probable that Porto suffered at the start of the 16th Century from the concentration of an overseas trade monopoly in Lisbon, a phenomenon that was one of the key themes in the development of the capital city of the territorial State at the start of the Modern Era. During this period, therefore, the international maritime trade of the city went through a phase of strategic adaptation and reformulation, which entailed the creation of new destinations for its ships. The New Spanish Christians, coming from Castile and arriving in Porto in 1491, played an essential role in these transformations. Simultaneously, they contributed to the growing social complexity of the city, forming an important group capable of competing in economic terms with an urban elite in which there were visible signs of crisis. With their access to international contacts, they created powerful commercial companies and participated, firstly in trade with the Portuguese islands in the Atlantic, a key step in the economic revival of the city, then, in a second phase in mid-century, with Brazil, the Indies of Castile and Flanders. Thus, while the traditional elite, on becoming dependent on the Crown, became associated with a parasitical economy, the entrepreneurial individualism of the New Christians put the city at the centre of the dynamic landscape of urban networks. The activity and success of the New Christians, however, contributed reactively to the progressive institutionalisation and embedding of the central cultural, economic and social place to which we referred above. Increasingly dependent on the Crown, the old elite was shut out - from the 1550s, for example, the institution of entailments banned marriages with New Christians - and their actions against the converts were not more significant only because the Atlantic free trade practised by them propelled the city into an era of progress which obviously benefited it. Porto society, therefore, became much more complex than in Mediaeval times. As if this were not enough, it had to cope with newcomers who were wealthier, better educated and better integrated into already modern, wider, more responsive and effective commercial networks. The somewhat mysterious activities in which they engaged made the old merchants seem plebeian.

The bishopric of D. Baltasar Limpo coincided with these transformations. At the start, the Carmelite was also associated with a neoplatonic and humanist programme, that of the Serra do Pilar monastery (begun 1537). With its dual Augustinian rotunda, the monastery was also conceived to act as an important landmark for navigation approaching the river port of Ribeira. Later, he collaborated with the reformer Friar Brás de Barros, a key figure in the construction of the Serra monastery. Together with him, they commissioned in 1540 the same Diogo de Castilho who was in charge of the Serra works, along with João de Ruão, to construct a college in Rua da Sofia in Coimbra, originally intended for the diocesan clergy of Porto and eventually allocated to members of their Order, works that were associated with the new concept of city that Baltasar Limpo upheld and to the renewed role of guide and reformer that its pastor should perform. These principles were clearly expressed at the time of his solemn entrance into Porto on 24 May 1537.

For the ceremony, Baltasar Limpo chose not the New Gate, where royal entrances were usually made, but the parish church of S. Pedro, in the suburb of Miragaia. He disembarked from a skiff on the sandy shore in front of the temple, equipped and adorned with flags by the Borough and, after entering the church, took the relic bust of St. Pantaleon which contained the remains of the martyr into his hands. Beneath a canopy supported by six clergymen, he then carried the relics in solemn procession to the Cathedral.

Through the invocation of a founding myth, Baltasar Limpo stressed the continuity of the History of the Christian city, since the church of S. Pedro was, according to the tradition of which D. Rodrigo da Cunha tells us about 90 years later, the temple that housed Porto's first Cathedral, whose first Bishop would have been St. Basil. D. Rodrigo da Cunha readopted a mediaeval tradition, published for the first time in 1513, but then adapted to the saga of St. Pantaleon. According to this memory, it was Roman Christians, carrying with them the remains of St. Pantaleon, who were the founders of the riverside temple and, therefore, of the city itself.

It is possible, in accordance with the humanist notion of "reformatio", according to which the eternal truths of medieval culture, the "deformatio", should be considered ephemeral and debatable, that Baltasar Limpo had intended to question the memory of the origin of the city, and relocate it to the Cathedral. If that was so, he will have prematurely understood that the ritual could rewrite the urban tradition, and therefore be a key element in a strategy whose aim was to strengthen the centrality and authority of 
the Cathedral. After three decades and two Bishops (the brothers D. Jorge and D. Pedro da Costa) whose tenure was marked by abandonment and neglect in pastoral affairs, that authority had been seriously undermined, making it urgent to continue the work begun by D. Diogo de Sousa, for its definitive consecration as a place of symbolic preeminance. The importance of ritual in the genesis of the city had been established at least since Ancient Greece. Baltasar Limpo, on the eve of the Council of Trent and the Counter-Reformation, of which he is considered a precursor, at a time of deep transformations and intense ideological and religious debate, invested it not only with its traditional role of urban unifyer, but also with an innovative capacity for steering the city in a new direction.

Baltasar Limpo understood that ritual had become a major form of integration and ideological control. In this sense, he was also amongst the first to realise the necessity to discipline its iconography. His Constitutions, following those of D. Miguel da Silva, insisted, based on a concept of Erasmus, “....because external things give a signal and understanding of the virtue and honesty within..."[14] on the importance of the public image of the clergy. The same principle gave rise at this time to the removal of non-religious activities from the cathedrals, and led Baltasar Limpo to purge the profane from the procession of "Corpus Christi". Subsequently, since ritual would be taken as a decisive element in "Christianisation", understood as the dynamic re-sacralisation of the urban space, the Council of Trent would examine the issues related to the reinstatement of outward observances, thus clarifying the public image of the clergy. Thus, a series of prohibitions and the strict regulation of processions would be formalised in the Constitutions of Friar Marcos de Lisboa (1585). They had a particular focus on the public image of the clergy and, in the Statutes of the Chapter House, published under Bishop D. Jerónimo de Meneses, the notion of decorum in the public place in which the procession would take place, was also emphasised, with bans falling on the dress of participating canons as well. All this regulation resulted, largely, from the increase in ritual arising from "Christianisation". It had its parallel in the clarifying directives on religious art issued by Trent and incorporated in the Constitutions of Friar Marcos de Lisboa, occurring alongside an intensification in the production of municipal bylaws. Regulations, rituals, and municipal bylaws were responsible for significant changes in the way of looking at the street, which was now seen as a fundamentally political reality, where the standards

(Cf. AFONSO)

[14] CONSTITUIÇÕES, 1541, p. 63. for structuring a community were applied, standards that, as such, would condition the existence of the city and, more than this, of the State itself. Processions brought a degree of mystical communion to the public space, capable of making it rise to a kind of independent purity. The monarch of the confessional State could be proud of being their source, since not only the general laws regulating the street but also, frequently, those that drove its representation through ritual, emanated from him. The effectiveneess of these actions, however, was far from being absolute, just as the power of the Modern State and its urban intervention were far from being absolute. Nostalgia for the expansive and fluid mediaeval space was long-lasting and had enough repercussions and strengths to muddy the discriminating purity. Once again, these symptoms erupted in the ritual. Thus, in the 17th Century, the "Corpus Christi" procession would cease to pass through Rua dos Mercadores because the residents would place chairs in front of their houses to watch the cortège. In fact, it would take some time before the street stopped being regarded as the front patio for each house.

The process, therefore, was slow and not without contradictions, but the new dynamic relationship between urban space and power would accentuate something that survived from as early as the Middle Ages, but was now systematised: the first would be the privileged stage to enact the second, an enactment that would be done not only through ritual, but also by the increasingly intense use of the medium of architecture with which it was closely associated. There was, in effect, an explicit relationship between both: Alberti, in the church of Sant'Andrea of Mantua, had already explored the rhetoric capacity of architecture, in its interaction with the urban landscape, through its localisation in a point of great ritual density.

The plaza in front of the porch of S. João, inside the Vandoma Gate, and the churchyard in front of the Cathedral adjacent to it, were places used since the Middle Ages for the departure and return of processions and ceremonial parades for the entrance of monarchs and ecclesiastical dignitaries, and naturally had identical capacities. It was here, where regulations and restrictions relating to the vicinity of the sacred, to the symbolism of the gates and the solemn, slow pace of arrivals and departures, that the secular building of the City Hall was erected in the early 15th Century. In the 1500s, the roles were reversed and it was the turn of the renewed religious power to invest in the square. The work was begun by D. Diogo de Sousa, who replaced the old mediaeval porch of the Cathedral with a "modern"type porch, and it was continued in other ways by 
Baltasar Limpo.

The intervention of the Carmelite in the environs of the Cathedral had a close antecedent in the Foz of D. Miguel da Silva, just as the public image of his clerics had a precursor in the priests of Viseu; both assumed a representative quality through the telling of a story, which was able to interact with the surrounding environment, integrating the space added at the end of the Middle Ages in a unified narrative. The remand prison and the ecclesiastical auditorium, the fountain, the design, which never came to fruition, of a new City Hall in which the representative, horizontal subjectivity of the façade replaced the objectivity of the vertical symbolism of the tower; the chapel of Nossa Senhora de Agosto, probably a layout based on an original plan centered; the reorganisation of the interior of the cathedral through the ordering of the altars and its pinnacle in the revolutionary crosspiece dome, with lantern and internal baluster veranda, which the Sicilian master André, possibly sent for from Italy by D. Miguel da Silva with Francisco de Cremona, made in the transept. The coherent narrative with which the interior and exterior spaces of the cathedral were invested pressuposed the existence of a plan that was, in fact, presented to the Councillors in 1537: in front of the porch, this plan transformed the mediaeval square into a "Plaza".

Baltasar Limpo thus deepened the policy begun by D. Diogo de Sousa, taking the different activities of pastor, builder and governor further, while the sacred nature of the first always placed it far above the other two. It was a humanist attitude that, as we said, went back to Nicholas $V$ and saw, in the promotion of architecture by ecclesiastical dignitaries, whether sacred or profane, a way to better fulfil their duties to God. In the new Praça de S. João, the syntagmatic and self-sufficient ensenble of the old square broke down. If it was conceived to be lived in, Baltasar Limpo's plan transformed it into a space that, essentially, was intended to be perceived.

\section{4 | The fortress}

The convent of S. Bento da Ave-Maria was erected in 1518 in Porto, bringing together various rural communities from convents located in secluded spots: "... to house women and in which few works in the service of God were performed...". The prophylactic and cleansing function of the city in relation to deviant behaviour allowed by the rural wilderness is evident in this excerpt from the Royal order for the foundation. The theme was revisited on the building of Rua das Flores (1521), in which rurality and urbanity are associated with aesthetic features, respectively "deformity" and "ennoblement".

In fact, breaking with mediaeval tradition, Humanism accentuated the mastery of the city over the countryside, separating one reality that was previously inseparable. In this way, in the first half of the 16th Century, Porto attracted not only nuns lost in the desert of temptation, or a relic half-hidden in a suburb, but also the neighbouring grandees. The same cultural factor caused the "ennoblement" of Rua das Flores and the oligarchical city of the 16th Century in general, which succeeded the Common Good, to result from the aesthetisation of a social class. This migration of concepts originated in the transformations of the urban ideology occurred from the beginning of the Modern Era, at the expense of the decline of the mediaeval community spirit and the ideas of Aquinas. These considered the city as the urban framework through which man could impose himself on a natural environment that was in no way inferior to him. The open city, which had the sole purpose of developing the Church's programme, founded on the idea of peace, happiness and harmony, premonitory of the kingdom of God. This was the ideal of justice and equality to which the Mendicants made a decisive contribution. Their alliance with the market, however, had detrimental side effects, hastening the end of the seigniorial system, and with it, the universal utopia of the Church. The Neoplatonic "Imago Urbis", which upheld the Christian view for more than a millennium, would eventually sink into the secular Mendicant ideal of the city of the Common Good and its political organisation.

At the beginning of the Modern Era, the Church also had a global project: the Catholic Counter Reformation of the mid 16th Century, the direct heir of the Humanism that preceded it came to be severely condemned. Now with the complicity of the State, it strove to make the sacred once more the centre of the world. In this plan, however, the Church would only retain its identification with the organicist metaphor from the old concept of Christian community. In Porto, demographic growth intensified in the first decades of the 16th Century, and the city expanded, but the social divisions became more pronounced. Processional life had been able to integrate and catalyse these elements, although it was already noticeable in the first decades of the century, that no-one appeared to know for certain what the place of Jewish converts was in the organicist plan. This was not the case, however, after the 1540s when, on the establishment of the court of the Inquisition, it became perfectly clear.

The new concerns of the confessional State would focus, therefore, on sealing the openings in the body mystic, expelling its heretics - which, at that time and place, meant the New Christians, active representatives of the innovative, free Atlantic trade - and seeking to keep all its members in good order. The 
boundaries of the new social body were drawn by the Inquisition proceedings that arise simultaneously with the Modern State, and especially through its grand moments of collective catharsis, the autosde-fé. Basically, the Inquisition served the objectives of the various constituent bodies of a State that was trying to regain control of a market that was quickly escaping it. In Porto, the court was created by King João III on 30 June 1541 and brought to an end by the Papal bull Mediatatio Cordis on 16 July 1547. It was then still Bishop Baltasar Limpo, who incidentally was one of those largely responsible for the final restoration of the Inquisition in Portugal and as a result was rewarded with advancement to Archbishop of Braga. During the period the court held sway in Porto, two autos-de-fé were carried out in the city, in 1543 and 1544, both outside the Olival Gate.

Sealing the social body was also carried out through the intensification of the processional ritual. From mid-century, celebratory, anti-heretic processions multiplied, parades having turned into a factor of drama and protection of the identity of the Catholic city. In 1555, under Bishop Rodrigo Pinheiro, a procession for the conversion of England was organised. Other similar ones followed, standing out amongst them that of 1272 which commemorated the massacre of St. Bartholomew, and another, two years earlier, that went from the Cathedral to S. Domingos. The Edict of Faith was then published, and a sermon was delivered by the Rector of the Jesuit College, Rui Vicente, both for the visit of the court of the Holy Office. The reorganisation of devotions through ritual consolidated a practice that, at the end of the Middle Ages, was already a fully developed structure. Trent enshrined it, declaring the processions a "sacred ritual". They became the leitmotiv of the post-conciliar ecclesia triunfans.

The main sign of urban transformation conveyed by ritual was, however, through altering the route of the most important procession, that of "Corpus". Its traditional route had kept the mediaeval city of the merchants open, since it would go, alternately, to S. Pedro de Miragaia and Santo Ildefonso, the two pre-Roman chapels outside the walls. However, from 1559 the route was restricted to a circuit inside the perimeter, starting and finishing at the Cathedral and particularly focusing on the old western ring road of the Rio da Vila valley. It is interesting to note that the City Council was aware of the pernicious effect that this measure would have on the council plots outside the walls of Santo Ildefonso, started in the expansion phase in the first half of the century. It decided that, at least on the eve of the "Corpus", banners and cerimonies would always go to Santo Ildefonso: "so as not to empty the streets" [15] (fig.6,7).

The restriction on rituals corresponded to the clos-

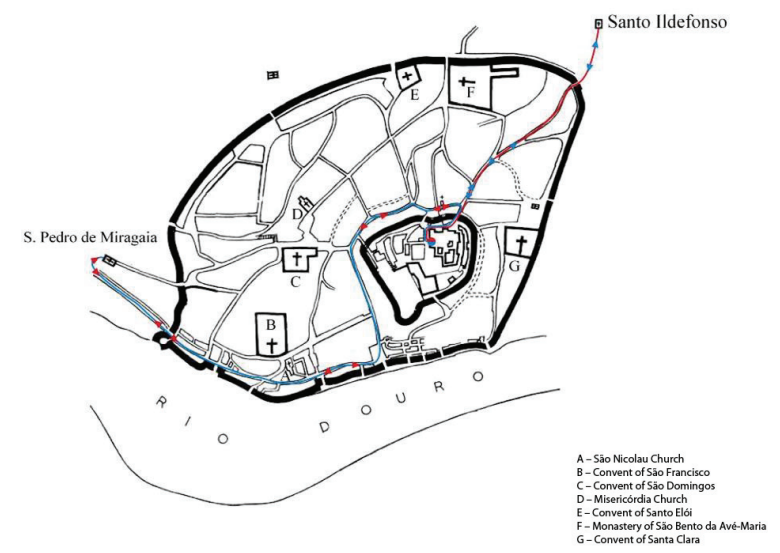

Figure 6: The procession of "Corpus" Christy before 1559

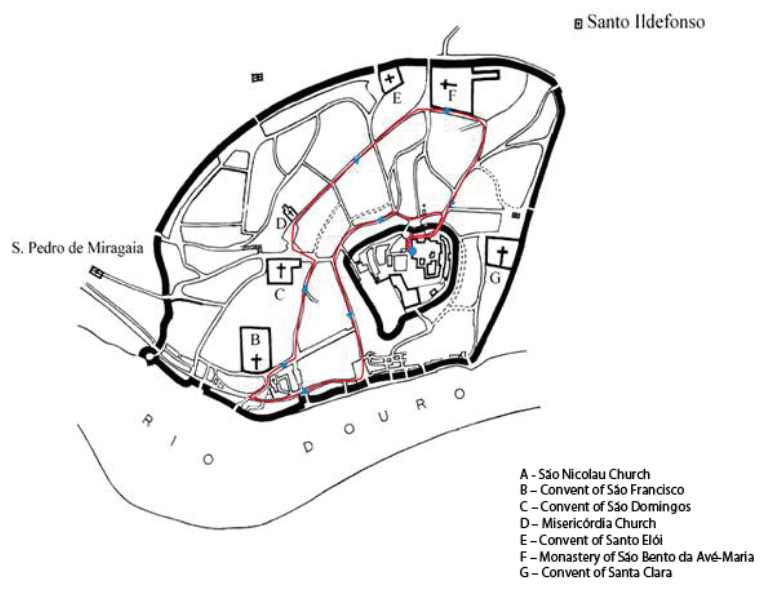

Figure 7: The procession of Corpus Christi after 1559

ing of the city: in the second half of the 1500 s, the pre-Mendicant Roman site, fearful behind its walled circle, burst back into the urban iconophilia. Note the words of Friar Manuel da Esperança when, in 1599, he alluded to the mediating action of St Pantaleon in the great plague that raged at the time and, miraculously, spared Porto:

"... Not only its neighbouring people of Massarellos, Gaia and Villanova were consumed, but also the suburbs that touch on its walls; all kept away time and again for ailing of this contagious illness, it always maintained its health through the intercession of the Virgin Mother and the holy merits of its patron saint..." [16]

The national Modern State took upon itself to bring to heel and surround the mediaeval city with fortifications. With the new urban cycle, the expansive "chõra" of D. Miguel da Silva, symbolised in the whole, identical to the Roman port of Ostia, which he undertook in the Douro and, above all, in its matrix, was finally immobilised inside a fortress. At the end

[15] Apud AFONSO. A Imagem, vol. 1, p. 132.

[16] ESPERANÇA, p. 396. 
of the century, one of the greatest, if not the greatest concern of the Porto officials was to reinforce the old wall and construct "modern style" bastions like the fort of S. Filipe next to the New Gate. This concern coincided with the unprecedented influx of a contingent of foreigners taking up residence in the city. A sacred circle of chapels strategically placed in gates and outside the walls doubled the defence, because the stones of the 16th Century wall were no longer the Mendicant symbol of the community of men, but the sign of their separation. They marked the area of activity of the Holy Martyr consecrated by the processional rites of protection, while also expelling to the outside heretics sentenced in the autos-da-fé. As a result, Atlantic trade suffered a tough blow with the flight and expulsion of the major New Christian families at the end of the 1620s. In Seville, giant hollow plaster statues with the condemned inside were even set on fire. At a time of intense iconophilia, the image of the wall was much stronger than its stones.

The increased symbolism of the walled perimeter would also delay the final disappearance of the distinction between inside and outside, or if you will, between the regulated, purified and highly ritualised urban area inside the walled city and the suburbs outside it, which were identified with the countryside. Thus, in the early 17th Century, Santo Ildefonso and Miragaia, outside the walls and excluded from the ritual of "Corpus", were, at least in the minds of Porto's inhabitants, still mainly areas of vegetable gardens, the same which in the first quarter of the previous century, debased the intramural city. In 1590, however, the records for the parishes located within the city walls listed no-one whose profession was a farmer. So it comes as no surprise to find references to the closure, even if occasional, of the proud New Carros Gate, built in 1526 at the northern end of Rua das Flores, which was supposed to welcome urban expansion beyond the walls. Apart from the avenue of Cordoaria and Carmo, it would only be reused in a structured way in the late 17th Century, with the construction of the Congregados and then, in the 18th Century, with the opening of the New Plaza.

The Counter-Reformation, as an essentially urban movement, only accentuated a culture of supremacy of the city, which ascended to Humanism, to "Devotio Moderna" and the first, still mediaeval, movements of Reform. Thus, models of belief and behaviour were proposed which, spreading from urban centres, were universally imitated. The city of the early Modern Era, an internalised bastion, far from the surrounding rural environment and its economically exploited inhabitants, became a mediator, not only between men but also between them and
God - the churches, like Correggio realised early on, were not only sacred places, but above all crossing points to the divine - which at that time also meant that it took a mediating position between them and the State.

\section{5 | The clear city: the image must stand out}

The Royal edict of 1559, which ordered the restriction of the "Corpus" procession to the interior of the walls, obeyed the desire for an urban image format, with the consequent dichotomy in geographical, political, social and significance terms between the inside and the outside of the walls. It was also able to formalise an "anima urbis" similar to that which Nicholas $\vee$ had made in Rome about a century before, as the processional route almost exclusively followed the valley of the Rio da Vila, its roads, including the Manueline residential areas and the city's historic markets, principally Ribeira and S. Domingos. At the same time, it contributed to the vertical and hierarchical aggregation of the urban social fabric, in a way that would be complemented by the creation of new parishes inside the walls in 1583.

The "Corpus Christi" ritual built a canonical narrative about Porto, returning to the example of the entrance of Baltasar Limpo in 1537. For this, however, certain prosperous areas, like Rua de S. Miguel, the old Jewish quarter and the western end of Belmonte, in which the Augustine convent of S. João Novo was founded in 1592, were excluded from its route. These were the residential areas favoured by the major New Christian bankers and were therefore associated with the new Atlantic economy. It did, however, pass through Rua das Eiras and Rua de Cimo de Vila, immediately before the Vandoma gate that gave access to the cathedral close, where the towers of several old patrician families in town were concentrated, particularly that of Rodrigues de Sá, Lord Mayors since King João I. Its aim was to produce a "pure" "public" area in Porto, roughly coinciding with the old Mendicant peripheral ring and the ritual aspect would contribute to its clarification in the actual intra-mural area. However, this anima urbis was not completely formalised, and according to the pioneering example of intervention in the Cathedral conducted by Baltasar Limpo, without the representative and identitary character of the architecture and the new means of graphic representation. It was the Jesuits who were largely responsible for this operation.

The Society of Jesus, which was one of the main catalysts of "Christianisation", fully understood the lesson of Alberti: the city was seen as a profoundIy ritualised stage, capable of capitalising on the representative possibilities of architecture. Like the Mendicants three and a half centuries earlier, their 
teaching concentrated on a persistent task of proselytism and urban evangelisation. From the city, the Jesuits would conquer a rural world they regarded as little short of barbaric. Father Inácio de Azevedo, from Porto, after travelling for two months in the province of Trás-os-Montes, declared its inhabitants to be stupid and rude; other Jesuit missionaries compared the Minho people to Gentiles and those from the Beiras to the Negroes of Guinea.

The first Jesuits arrived in Lisbon in 1540 and quickly established themselves in the most important Portuguese urban centres: Coimbra in 1542, Évora in 1551, Porto in 1560. The rapid arrival and expansion of the Society of Jesus was due to the invitation and protection of King João III. From the perspective of the Monarch, it was a well-prepared army capable of putting into practice the Portuguese plan for Christian evangelisation, which ran alongside that of expansion. It would also be able to strengthen Christian morals and worship in Portugal's European territory and reinvigorate a highly deficient culture and education. This is why the King came to be known as the second founder of the Society of Jesus. The Jesuits were also a decisive instrument in the final alignment of the "Pious King" with the Catholic Counter-Reformation, which led to the shift in political culture that occurred during his reign.

The Jesuit concept of the city as a sacred stage and, consequently, as the scene in which the procession and preaching representations should be simultaneously encapsulated, hardly fitted the cramped and claustrophobic setting of Barredo, next to Ribeira, where the Apostles, led by S. Francisco de Borja, settled on their arrival in Porto. Thus, they quickly moved to a new location on the high platform of Aldas on Penaventosa hill, next to the Cathedral. Besides reinforcing the idea of obedience, one of the fulcral concepts in the thinking of Inácio, the new locale provided the ideal conditions for an urban setting of an historical nature that the Society craved. In it, architecture was the final element in a long chain, whose links were the various formal, historical and symbolic components of the urban landscape. With this aim in mind, the Society did not neglect the optimisation of all the possibilities for articulation provided by the new forms of iconic representation. It is in this sense that the obligation to send to Rome the detailed plans of each city in which a new College was to be founded should be understood.

In Porto, however, the Society's architects, probably either Bartolomée de Bustamente or Silvestre Jorge, undertook an urban survey. This must have been prior to 1570, when the new site for the College had already been chosen. Three years later, on 20 August 1573, the first stone was laid for the College of S. Lourenço. This survey, without doubt one of the first to be made of the city, would have followed the degree of objectivity and precision possible at the time. The scientific modernity of the Renaissance, however, as is evident in the thinking of one of its leading theorists, Alberti, a pioneer in the differentiation between graphic representation and construction, did not mean an abrupt break with the Mediaeval scholastic culture which, as a matter of fact, was one of the topoi of the Jesuits. This permanent dialectic between modernity and mediaevalism can, for example, be detected in the Aldas steps, in front of the College.

The steps, built from 1595, were intended to link, through their four flights, the Aldas terrace, where the College was sited, to the upper plateau of Penaventosa, where the Cathedral was situated. They fan out, framing the escarpment, in a semicircular landing inspired by an engraving by Serlio: it is a manifestation of the "concordatio" between the delicacy of art and the harshness of nature. It is also, in the wild "terribilita" of the escarpment, which is metamorphosed into the order and permanence of the semicircle of steps, an affirmation of the reality of the image and therefore of classical fullness borrowed from antiquity. This was its modernity; simultaneously, however, the way it overcomes the difficulties of the escarpment is the mirror image of the Neoplatonic ascension theory which, incidentally, was recovered by St. Ignatius in his Spiritual Exercises.

The same understanding of the possibilities and importance of the image presided over the choice of the site for the College of S. Lourenço, facilitating its close relationship with the city. However, in the absence of a plan, it could hardly have been achieved. Sited lengthwise on the narrow Aldas terrace, the College incorporated the movement of the old street existing there; it seems to advance on the city, with joyous, didactic and exemplary energy. This was perfectly justifiable, since the importance given by the Jesuits to the architecture and the site fits into the Ignatian method of "seeing the place" and owed much to the identification that the Society established between itself and education. This ranged from the construction of schools and churches to the establishment of brotherhoods, from preaching to the creation of theatrical pieces that quickly would be developed in the Colleges. In this sense, S. Lourenço was an urban performance, whose unabashed visuality was able to raise the spirit and character of the city's inhabitants. It is also, according to the Jesuit concept of art, a morally uplifting story, the mediator subject of individual experience, capable of guiding the senses, the intellect and the spirit of everyone. 


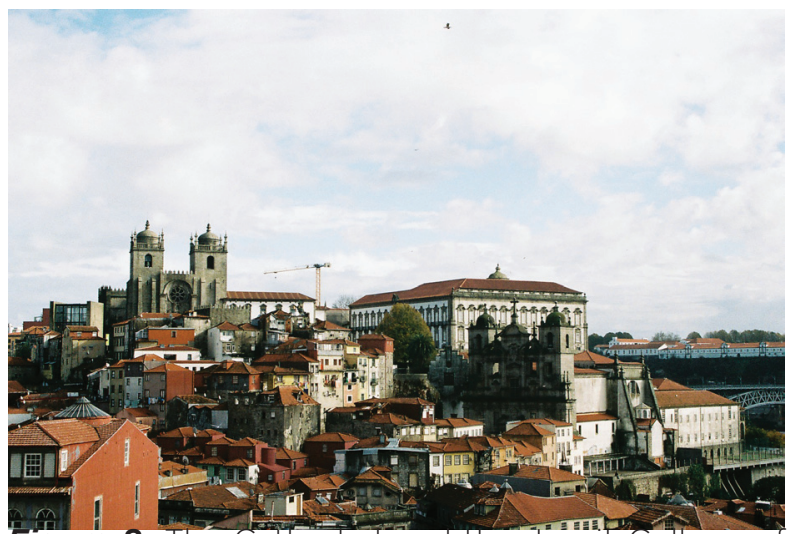

Figure 8: The Cathedral and the Jesult College of São Lourenço (bottom right)

S. Lourenço dominated the valley of the Rio de Vila, while submitting hierarchically, in a creative counterpoint of tension, but not disharmony, to the Cathedral (fig. 8). It introduced a "Weltanshauung" into Porto; a new language of the visible. Two other reformed establishments quickly followed in its footsteps: S. João Novo (1593), which, in the same way, had its façade facing the city and S. Bento da Vitória (1598), whose foreshortened façade rose at the top of the hill of the old Jewish quarter, facing the cathedral. The classic principle of a live harmony, arbitrarily formed, seems to have presided over this arrangement, subordinate and semi-circular, around the Cathedral and the valley of the Rio da Vila. This, become "anima urbis", established itself as the place of the plot, woven by the eye, between the religious architectures that rejoiced with mutual vision and afforded, like the ritual man "... the bright feeling of being like the others ..." [17].

The analogical thinking, long-held in Western culture, from Ambrose to Thomas Aquinas and from Scotus Erigena to Saint Augustine [18] concurred in this way, alongside the scientism of the new iconic ways of graphic representation, for the renewed plan for the valley of the Rio da Vila. But the presence of large architectural masses - the new Casa da Relação would be erected next to the Benedictine monastery from 1607 - also expressed the ubiquity of Church and State. In Porto, they were the most visible signs of the "Petrifaction" movement that invaded the European city of the modern age. As synoptic and hyper-representative architectures, they showed such a strong desire to materialise the dogma that little remained in them of the im-

[17] MISHIMA. Le Soleil et I'Acier. Apud LEGENDRE, Pierre. Margin note. Un object digne d'acclamations ... Soulever la Question liturgique en Occident. In: KANTAROWICZ, Ernst C. Laudes Regiae. Une étude des acclamations liturgiques et du culte du souverain au Moyen Âge, Paris: Fayard, 2004, p.10.

[18] TAFURI, p.31. penetrability of the old symbol. Their transparency resulted from the policy of consensus and social identity around the confessional State, implemented after the middle of the century by King João III, who ritually demarcated the "anima urbis", structured it and vertically framed it by the division into parishes and sealed it by the ritualised organicist metaphor. The primacy of representation, however, had begun well before in the valley: the Dominican centrality had decrypted the absolute symbolic space in the ideal of the Common Good; the Joanine Ribeira and Jewish quarters fragmented it into the exclusive regulated urbanism, and the morphologically and socially hierarchicised extensions of King Manuel initiated their modern systematisation.

At the start of the 17th Century, the image should jump out of the picture. The shadow in which the eastern city from the Penafiel road and the suburbs were plunged would enhance the pure clarity of the narrow Mendicant valley. A contiguity that was required to make the "Weltanshaung" effective, reinforcing the theatrical exposure of the State through the variety and suitability of the representations. A State that, like a system of hierarchical differences and oppositions, is recognised through the immediately noticeable visuality of the signs inflated by the ostentatious practices of the architecture.

Porto thus acquired the façade, in the full sense of "facies", that remained with the city throughout the Modern Era. It gave it a clear and instantly recognisable identity, a result of the stratigraphic dialectic between the mediaeval ichnographia, the 15th Century exclusivity, the Manueline expansion and the actions of the Counter-Reformation that the Baroque would only refine. An "istoria" had already been tried by
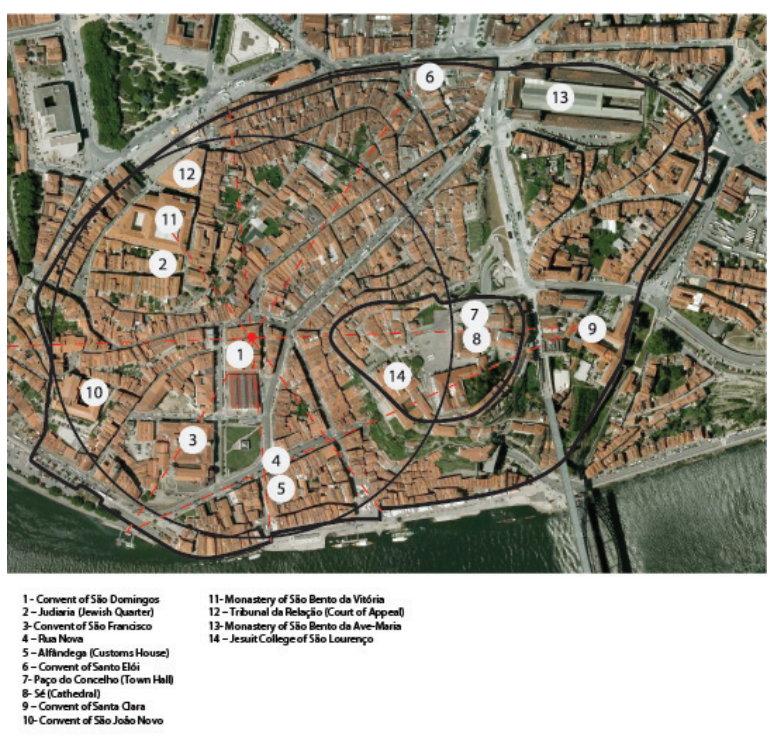

Figure 9: The city plan in the 16th Century 


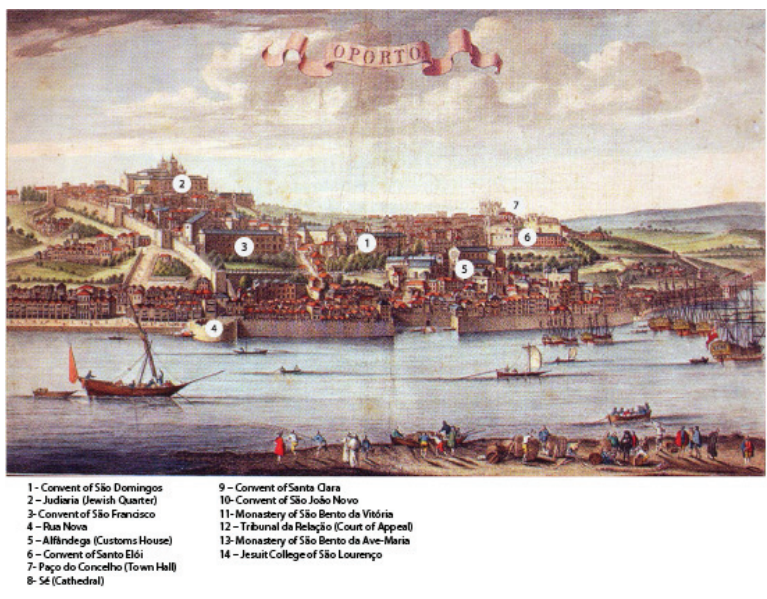

Figure 10: The anima urbis in an engraving of the 18th Century

Baltasar Limpo in Praça de S. João. In Catholic Porto, the image of the city narrated in the stone and in the skyline its history, made social, political, theological, urban and iconographic dogma (fig. 9,10).

\section{REFERENCES}

[1] AFONSO, José Ferrão. A imagem tem que saltar ou o rebate dos signos. A cidade episcopal e o Porto intramuros no século XVI. Propriedade, ritual, representação e forma urbana (1499-1606). [Roneoed text]. 3 vols. Barcelona, 2008. Dissertation (PhD in the Theory and History of Architecture). Barcelona School of Architecture, UPB.

[2] A Praça da Ribeira (part 1). Revista Mvseu (at press).

[3] ALMEIDA, Carlos Alberto Brochado de. Via Veteris. Antiga via romana? Actas do Seminário de Arqueologia do Noroeste Peninsular. 3 vols. Guimarães: Sociedade Martins Sarmento/Revista de Guimarães, 1980, vol. 3, p. 155 et seq.

[4] ALMEIDA, Carlos Alberto Ferreira de. Vias medievais de Entre Douro e Minho, Dissertação para a licenciatura em História [Roneoed edition]. Porto: Faculty of Letters, 1968.

[5] ALVES, Ana Maria. Iconologia do poder real no período manuelino. A procura de uma linguagem perdida. Lisbon: INCM, 1985.

[6]AZEVEDO, Carlos Moreira. Pantaleão de Nicomédia: percurso biográfico, na memória da persistente devoção europeia. In: Esta é a cabeça de S. Pantaleão. Lisbon: IPM, 2003, p. 91 et seq.

[7] BARROS, Amândio Jorge Morais. A procissão de Corpo de Deus do Porto nos séculos XV e XVI: a participação de uma confraria. Revista da Faculdade de Letras. História, 2nd series, 10 (1993), p. 117 e ss. BARROS, Amândio Jorge Morais. Alterações nas elites mercantis portuguesas no tempo dos Reis Católicos. O caso da cidade do Porto. In: Congreso Internacional Isabel La Católica y su época (Luis Ribot Garcia and Julio Valdeón Baruque, coords.). Valladolid-Barcelona-Granada 15 to 20 November 2004, p. 2 et seq. (at press).

[8] BARROS, João de. Geographia d'Entre Douro e Minho e Tras-os-Montes. Porto: Porto Municipal Public Library, 1919.

[9] BASTO. Artur Magalhães. O estabelecimento da Companhia de Jesus no Porto. Boletim Cultural da Câmara Municipal do Porto, 4, fasc. I (March 1941), p. 25-49; 5, fasc. I (March 1942), p. 36-57.

[10] BETHENCOURT, Francisco de. História das Inquisições. Portugal, Espanha e Itália. Lisbon: Círculo de Leitores, 1994.

[11] BRANDÃO, Domingos de Pinho. Teologia, filosofia e direito na diocese do Porto nos séculos XIV e XV. Alguns subsídios para o seu estudo. Studium Generale. Boletim do Centro de Estudos Humanísticos, 7 (1960), p. 242 et seq.

[12] BUESCU, Ana Isabel. Imagens do príncipe. Discurso normativo e representação (1525-1549). Lisbon: Edições Cosmos, 1996.

[13] CALABI, Donatella. The market and the city. Square, Street and Architecture in early Modern Europe. Aldershot: Ashgate, 2004.

[14] CAMPOS, Fernando. As devoções de D. João II. Esta é a cabeça de S. Pantaleão. Lisboa: IPM, 2003, p. 53 et seq.

[15] CARDOSO, Isabel Botelho. Concelho e senhorio. O Porto (1385-1433). Master's thesis in Mediaeval History for the Faculty of Letters of the University of Porto [Roneoed edition]. Porto: FLUP, 1993.

[16] CARITA, Helder. Lisboa Manuelina e a formação de modelos urbanísticos da época moderna (14951521). Lisbon: Livros Horizonte, 1999.

[17] CHOAY, Françoise. Urbanism and semiology. The city and the sign. An introduction to urban semiotics (M. Gottdiener; Alexandros Ph. Logopoulos, eds.). New York: Columbia University Press, 1986, p. 160 et seq. 
[18] COMBLIN, Joseph. Théologie da la ville. [s.l.]: Éd. du Témoignage Chrétien, 1968.

[19] CROUZET - PAVAN, Élisabeth. Sopra le acque salse». Espaces, pouvoir et societé à Venise à la fin du Moyen Âge, 2 vols. Rome: École française de Rome, Palais Farnèse, 1992. Collection de l'École Française de Rome, 156

[20] CRUZ, António. Um reformador pré-tridentino. D. Frei Baltasar Limpo prelado do Porto e de Braga. Boletim Cultural da Câmara Municipal do Porto, 25, fasc. 3-4 (January/December 1980), p. 91 et seq.

[21] CONSTITUIÇÕES Synodaes do Bispado do Porto ordenadas pello muito Illustre \& reverendissimo Senhor Dom frey Marcos de Lisboa Bispo do dito Bispado. Coimbra, Por Antonio de Mariz, 1585.

[22] CONSTITUIÇÕES sinodaes do bispado do Porto ordenadas pelo muito reverendo e magnifico Senhor Dom Baltasar Limpo Bispo do dicto bispado. Porto: Vasco Dias Tanquo de Frexenal, 1541.

[23] COUTO, Padre Luís de Sousa. Origem das procissões da cidade do Porto. Porto: Câmara Municipal do Porto/Gabinete de História da Cidade, 1936. Documentos e Memórias para a História do Porto, 1

[24] CUNHA, D. Rodrigo da. Catalogo dos Bispos do Porto, 2 vols. Porto: Officina Prototypa Episcopal, 1742.

[25] DIAS, José Sebastião da Silva. A política cultural da Época de D. João III, 2 vols. Coimbra: University of Coimbra, 1969

[26] Correntes do sentimento religioso em Portugal (Séculos XVI a XVIII), 2 vols. Coimbra: University of Coimbra, 1960.

[27] ESPERANÇA, Frei Manuel da. Historia serafica da ordem dos frades menores de S. Francisco na Província de Portugal, 2 vols. Lisbon: Oficina Craesbeekhiana, 1656.

[28] FERREIRA, J. Augusto. Memorias archeologico historicas da cidade do Porto (Fastos Episcopaes e Políticos). 2 vols. Braga: Cruz \& Compa Editores, 1923. FOUCAULT, Michel. As palavras e as coisas. Lisbon: Edições 70, 2005

[29] FREGNA, Roberto. La pietrificazione del denaro. Studi sulla proprietà urbana tra XVI e XVII Secolo. Bologna: Editrice Bologna, 1990.
[30] FREITAS, Eugénio de Andreia da Cunha e. Estradas velhas entre Leça e Ave. Douro Litoral, IV Série I-II (1950), p. 50 et seq

[31] FRUGONI, Chiara. A distant city. Images of urban experience in the medieval world. Princeton: Princeton University Press, 1991.

[32] GOMBRICH, E. H. Symbolic Images. In: Gombrich on the Renaissance, 2 vols. London: Phaidon, 1993, vol. 2.

[33] GUIDONI, E.. Città e ordini mendicanti. II ruolo dei conventi nella crecità e nella progettazione urbana del XIII e XIV secolo. Quaderni Medievali, 4 (1977), p. 69-106.

[34] HESPANHA, António Manuel, As vésperas do Leviathan. Instituições e poder político. Portugal séc. XVII. Coimbra: Almedina, 1994.

[35] HUIZINGA, Johan. The Waning of the Middle Ages. Hardmondsworth, Middlesex: Penguin Books, 1990

[36] E GOFF, Jacques. L'apogée de la France urbaine médiévale, 1150-1330. In: DUBY, Georges (dir.) Histoire de la France urbaine. Paris: Seuil, 1981, vol. 2, p.183 et seq.

[37] EFEBVRE, Henri. La production de l'espace. Paris: Anthropos, 2000.

[38] LEGENDRE, Pierre. Margin note. Un object digne d'acclamations ... Soulever la Question liturgique en Occident. In: KANTAROWICZ, Ernst C. Laudes Regiae. Une étude des acclamations liturgiques et du culte du souverain au Moyen Âge, Paris: Fayard, 2004, p.9 et sea.

[39] LILLEY, Keith D. Cities of God? Medieval urban forms and their Christian symbolism. Transactions of the Institut of British Geographers, 23 (September 2004), p. 296 et seq.

[40] LUCAS, Thomas M., S.J. Landmarking. City, Church \& Jesuit Urban Strategy. Chicago: Loyola Press, 1997.

[41] MACEDO, Maria de Fátima. "Esta: cabeça: leixou: Gonçalo da Cunha: meio cónego". In: Esta é a cabeça de S. Pantaleão. Lisbon: IPM, 2003, p. 251 et seq.

MACHADO, Ana Paula. Histórias em torno das relíquias e dos relicários de São Pantaleão no Porto. In: Esta é a cabeça de S. Pantaleão. Lisbon: IPM, 2003, p. 185 et seq. 
[42] MARTINS, Fausto Sanches. A Arquitectura dos primeiros colégios jesuítas em Portugal: 1542 -1759: cronologia, artistas e espaços [texto policopiado]. Porto 1995. Dissertation (PhD in History, specialisation in Art, presented at the Faculty of Letters, University of Porto).

[43] O Colégio de S. Lourenço 1560-1774. Summary paper for aptitude tests for a career in teaching [Roneoed edition]. Porto: FLUP, 1986.

[44] MATTOSO, José. A história das paróquias em Portugal. In: IDEM. Portugal medieval. Novas interpretações. Lisbon: INCM, 1985, p. 37 et seq.

[45] V. «Paróquia». In: AZEVEDO Carlos Moreira de (dir.) Dicionário de História Religiosa de Portugal. 4 vols. Lisbon: Círculo de Leitores, 2000, vol. 4, p. 372 et seq.

[46] MEA, Elvira Cunha de Azevedo. A Inquisição de Coimbra no século XVI. A instituição, os homens e a sociedade. Porto. Fundação Eng.- António de Almeida, 1997.

[47] MENDES, Nuno Resende. Corpo em estilhaços. O culto patronal a São Pantaleão "do Porto". In: Esta é a cabeça de S. Pantaleão. Lisbon: IPM, 2003, p. 124 et seq.

[48] MUIR, Edward. Ritual in Early Modern Europe. Cambridge: Cambridge University Press, 1997 NASCIMENTO, Aires de; GOMES, Saul. S. Vicente de Lisboa e os seus milagres medievais. Lisbon: ed. Didaskália, 1988.

[49] NOVAIS, Manuel Pereira de. Anacrisis Historial, 4 vols. Porto: Biblioteca Pública Municipal, 1912-1915 O'MALLEY, John. Trent and all that. Renaming Catholicism in the Early Modern Era. Cambridge, Massachussetts/London, England: Harvard University Press, 2000.

[50] OZMENT, Steven. The Age of Reform 1250-1550. An Intellectual and Religious History of Late Medieval and Reformation Europe. Yale: Yale University Press, 1981.

[51] ROSSA, Walter. A cidade portuguesa. In IDEM. A urbe e o traço Uma década de estudos sobre o urbanismo português. Coimbra: Almedina, 2002, p. 194 et seq.

[52] O urbanismo regulado e as primeiras cidades coloniais portuguesas. In: IDEM. A urbe e o traço. Uma década de estudos sobre o urbanismo portu- guês. Coimbra: Almedina, 2002, p. 361 et seq. RYKWERT, Joseph. La idea de ciudad. Antropología de la forma urbana en el Mundo Antiguo, Madrid: Hermann Blume, 1985.

[53] SILVA, Francisco Ribeiro da. A criação das paróquias de S. Nicolau e Na Sa da Vitória (1583). Aspectos sócio-económicos e religiosos da época. Porto: Paróquias de S. Nicolau e № S ${ }^{a}$ da Vitória: 1984.

[54] O Bispado do Porto à luz das Constituições Sinodais da Época Moderna: valores clericais e normas de comportamento. In: I Congresso sobre a Diocese do Porto. Tempo e lugares de Memória. Homenagem a D. Domingos de Pinho Brandão. Minutes, 2 vols. Porto/Arouca: Centro de Estudos D. Domingos de Pinho Brandão/Universidade CatólicaCentro Regional do Porto/Faculdade de Letras da Universidade do Porto-Departamento de Ciências e Técnicas de Património, 2002, vol. 1, p.57 et seq.

[55] O Porto e o seu termo (1580-1640). Os homens, as instituições e o poder, 2 vols. Documentos e Memórias para a História do Porto, XLVI. Porto: Porto City Council Historical Archive, 1988.

[56] SOALHEIRO, João. São Pantaleão entre o mundo antigo e os novos mundos. "Orientale lúmen". Esta é a cabeça de S. Pantaleão. Lisbon: IPM, 2003, p. 69 et seq.

[57]TAFURI, Manfredo. Sobre el Renacimiento. Princípios ciudades, arquitectos. Madrid: Cátedra, 1992.

WESTFALL, Carrol William. In this most perfect paradise. Alberti, Nicholas $V$, and the invention of conscious urban planning in Rome, 1447-55. University Park and London: the Pensylvania State University Press, 1974.

[58 ]WHITEHAND, J.W.R. Reflexiones sobre la morfologia urbana. WHITEHAND, J.W [et al.] Morfologia Y paisage urbanos: la perspectiva geográfica británica. Lleida: Department de Geografia y Història, Facultat de Lletres, Universitat de Lleida, 1989, p. 9 et seq.

\section{FONTS}

Figure 4 - Photo by José Pessoa, published in: Esta é a cabeça...

Figures 5, 6, 7 - Based on carthograms published in: OLIVEIRA, J.M. Pereira de. O Espaço urbano do Porto. Condições naturais e desenvolvimento. 2 vols. Coimbra: Instituto de Alta Cultura - Centro de Estudos Geográficos, 1973 